\title{
Suitability of Nano-sulphur for Biorational Management of Powdery mildew of Okra (Abelmoschus esculentus Moench) caused by Erysiphe
} cichoracearum

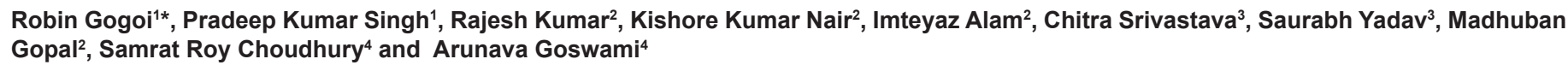

${ }^{1}$ Divisions of Plant Pathology, Indian Agricultural Research Institute, New Delhi 110 012, India ${ }^{2}$ Divisions of Agricultural Chemicals, Indian Agricultural Research Institute, New Delhi 110 012, India ${ }^{3}$ Department of Entomology, Indian Agricultural Research Institute, New Delhi 110 012, India ${ }^{4}$ Indian Statistical Research Institute, Kolkata-700 108, West Bengal, India

\begin{abstract}
New nano-sulphur synthesized at IARI and three other commercial products namely commercial sulphur (Merck), commercial nano-sulphur (M K Impex, Canada) and Sulphur 80 WP (Corel Insecticide) were evaluated in vitro for fungicidal efficacy at $1000 \mathrm{ppm}$ against Erysiphe cichoracearum of okra. All the sulphur fungicides significantly reduced the germination of conidia of E. cichoracearum as compared to control. Least conidial germination was recorded in IARI nano-sulphur (4.56\%) followed by Canadian nanosulphur (14.17\%), Merck sulphur $(15.53 \%)$, sulphur 80 WP (15.97\%) and control (23.09\%). Non-germinated conidia count was also high in case of IARI nanosulphur followed by Canadian nano-sulphur, Merck sulphur and Sulphur 80WP. Apart from inhibition of conidial germination, cleistothecial appendages were also disrupted in contact with nano-sulphur and the cleistothecia became sterile. The study proved that IARI nano-sulphur is more effective than the commercial formulations and could be applied at lower amount for controlling powdery mildew disease for its better efficacy.
\end{abstract}

Keywords: Sulphur; Fungicides; Nano formulations; Powdery mildew; Okra

\section{Introduction}

Powdery mildew is a serious disease of okra, beans, southern peas, squash, cucumbers, muskmelons, and pumpkins in almost all the areas of the country. The disease is caused by the fungus Erysiphe cichoracearum DC ex Merat [Sphaerotheca fuliginea (Schlecht ex Fr.) Poll.)]. Other species of Erysiphe like E. polygoni causes powdery mildew in beans, southern peas, and English peas and Sphaerotheca macularis affects strawberries. Okra or Bhindi or Lady's finger (Abelmoschus esculentus Moench) is an important vegetable crop. Most of the okra cultivars are susceptible to powdery mildew disease, and depending upon the age of the plant at the time of infection, yield losses range between 17 and $86.6 \%$ [1]. The disease is favored by low temperature $\left(11-28^{\circ} \mathrm{C}\right)$ and dry weather conditions and early infection has more effect on the plant growth and yield than late infection [2]. Effective control of the disease is possible with fungicidal applications and the recommended fungicides are benomyl $(0.1 \%)$, wettable sulfur $(0.2,0.3$ and $0.5 \%)$ [2,3]. Applications of potassium silicate $\left[\mathrm{K}_{2} \mathrm{SiO}_{3}(200 \mathrm{mg} / \mathrm{L})\right]$ and the alternation of systemic fungicide Bayleton WP 5 [Triadimenol $(25 \mathrm{mg} / \mathrm{L})$ ] and Thiovit 80\% WP (sulfur $(2.4 \mathrm{~g} / \mathrm{L})$ ) with 12 day interval were also highly protective against powdery mildew [4]. Among these fungicides, elemental sulphur $\left(\mathrm{S}^{\circ}\right)$ is universally known as the most effective one for managing powdery mildews and this fungicide has been used as foliar spray @ 2-4 g per litres (2000-3000 ppm).

As against achieving effective control of powdery mildew disease by using sulphur fungicides, phytotoxicity may be an adverse effect of this fungicide even at recommended doses or due to over use. Hence, it was advised for restricted use of sulphur fungicides in the fruit plants like apple [5] and apricot, vegetables like spinach, melon and squash. To avoid the risk of phytotoxicity, threat to non-targeted organisms and the environment, an idea was conceived to have better control of powdery mildews using lower or safe doses of fungicides.
Recently, nanoformulations (particle size $<100 \mathrm{~nm}$ ) of pesticides have been able to draw much attention due to their higher efficacy even at very low doses, because nanoparticles could be more chemically reactive and bioactive than larger particles [6]. We have developed nano-sulphur having $50-90 \mathrm{~nm}$ particle size by liquid synthesis method [7] and also standardized a simple method for estimation of active ingredient of sulphur nanoformulation [8]. Subsequently, sulphur nanoparticles were characterized by using dynamic light scattering (DLS) study, transmission electron microscopy (TEM), scanning electron microscopy (SEM) and energy-dispersive X-ray spectroscopy (EDAX) [8]. The reasons of choosing sulphur for developing into nanoform are that firstly, micronized elemental sulphur $\left(S^{\circ}\right)$ has been in use as a fungicide since long time more particularly in controlling powdery mildew diseases of crops and secondly, this element is having multipronged applications such as fertilizer, pharmaceutical, antimicrobial agent, insecticide, fungicide, high density charger in lithium ion battery as well as rubber and fibre industries [9-15].

Our sulphur nanoparticles exhibited significantly superior fungicidal properties than the conventional sulphur against a food contaminant Aspergillus niger [7]. Therefore, further investigation was carried out on the efficacy of newly synthesized nano-sulphur against

*Corresponding author: Robin Gogoi, Divisions of Plant Pathology Indian Agricultural Research Institute, New Delhi 110 012, India E-mail: r.gogoi@rediffmail.com

Received January 31, 2013; Accepted March 21, 2013; Published March 26, 2013

Citation: Gogoi R, Singh PK, Kumar R, Nair KK, Alam I, et al. (2013) Suitability of Nano-sulphur for Biorational Management of Powdery mildew of Okra (Abelmoschus esculentus Moench) caused by Erysiphe cichoracearum. J Plant Pathol Microb 4: 171 doi:10.4172/2157-7471.1000171

Copyright: @ 2013 Gogoi R, et al. This is an open-access article distributed under the terms of the Creative Commons Attribution License, which permits unrestricted use, distribution, and reproduction in any medium, provided the original author and source are credited. 
crop diseases like powdery mildew of okra caused by E. cichoracearum.

\section{Materials and Methods}

\section{Collection and maintenance of the pathogen}

Okra leaves affected by E. cichoracearum showing the typical symptoms of powdery mildew disease were collected from vegetable farm of IARI, New Delhi. Profusely growing conidia were collected for artificial inoculation by using a camel hair brush and suspended in sterile distilled water containing Tween 20. The conidial suspension was then centrifuged at $3000 \mathrm{rpm}$ for $5 \mathrm{~min}$ twice, in order to separate conidia from conidiophores [16]. The concentration of the conidia was adjusted to $3 \times 10^{4}$ conidia $\mathrm{ml}^{-1}$ using a haemocytometer. This suspension was sprayed using an atomizer on the healthy leaves of 60 days old potted okra plants maintained in the poly house. After inoculation, the plants were covered by polythene bags for $24 \mathrm{~h}$ to maintain high humidity for disease development.

\section{In vitro evaluation of fungicides and spore germination}

Four non-systemic fungicides viz. commercial sulphur (Merck), commercial nano-sulphur (M K Impex, Canada) and Sulphur $80 \mathrm{WP}$ (Corel Insecticide) and IARI nano-sulphur were evaluated at 1000 ppm (or $0.1 \%$ ) concentrations under in vitro conditions against $E$. cichoracearum. Conidial germination was tested by two methods. In the first method, two percent water agar medium was used as a basal medium that was poured over a clean grease free glass slide. Fungicidal suspensions of $1000 \mathrm{ppm}$ were prepared in sterile distilled water under aseptic condition. Powdery mildew spores were added to each fungicidal suspension, adjusted the spore concentration as described earlier and smeared (three times per slide) on agar surface by using camel hairbrush. These slides were incubated at $25^{\circ} \mathrm{C}$ for $24 \mathrm{~h}$. Three replications were maintained for each treatment. In control, conidial suspension was prepared in sterile distilled water, spread on the $2 \%$ water agar surface and conidial germination was observed under microscope (Magnus MLXi, Olympus).

In the second method, the efficacy of fungicides was assessed based on the conidial germination of E. cichoracearum employing detached leaf method [17]. Fresh okra leaves were washed in sterile distilled water and air dried. Solution of the fungicide prepared at $0.1 \%$ concentration was sprayed on the adaxial surface of the leaf using an atomizer and allowed to air dry. The treated leaves were inoculated with three drops of conidial suspension of E. cichoracearum $\left(3 \times 10^{4}\right.$ conidia $\left.\mathrm{ml}^{-1}\right)$ and spread uniformly on the leaf surface using camel hairbrush. The leaves smeared with the conidial suspension without fungicide was served as a control. In each treatment, three leaves were placed in a petridish having moist tissue paper and incubated at $25^{\circ} \mathrm{C}$. Each treatment was replicated thrice. After $72 \mathrm{~h}$, powdery growth was observed on the inoculated leaves. Conidia from the superficial growth were dusted (five sweeps from each leaf for one slide) on water agar coated slide using a hair brush, incubated again for $24 \mathrm{~h}$ and observed under fluorescent microscope (at 10X). The germinated and non-germinated conidia and also their total number were counted from three microscopic fields. The percent germination was calculated by using the formula: $\mathrm{PG}=(\mathrm{A} / \mathrm{B}) \times 100$, where, $\mathrm{PG}=\mathrm{Per}$ cent germination, $\mathrm{A}=$ Number of conidia germinated and $\mathrm{B}=$ Total number of conidia examined.

\section{Results and Discussion}

In the present study, newly synthesized IARI nano-sulphur and other forms of sulphur were tested in vitro against powdery mildew of vegetables (okra) caused by E. cichoracearum and the results drawn out by executing two methods viz. poisoned food technique and detached leaf method (Table 1). All the sulphur fungicides highly inhibited conidial germination E. cichoracearum as compared to control in both the methods. In poisoned food technique, minimum $(2.95 \%)$ germination of conidia was observed in IARI nano-S followed by Merck sulphur, Sulphur 80WP and Canadian nano-S. As far as percent inhibition of conidial germination and non-germinated conidia are concerned, IARI nano-S exhibited significantly higher inhibition followed by Merck sulphur, Sulphur 80WP and Canadian nano-S. The performance of the latter three forms of sulphur was at par with control in terms of all the studied parameters of E. cichoracearum. In the second method, i.e., detached leaf method, IARI nano-S out performed which was followed by Canadian nano-S, Merck sulphur and Sulphur 80WP. However, percent inhibition of conidial germination in IARI nano-S was non-significant with Canadian Nano-S. Although conidial germination as recorded in Sulphur 80WP was less (4.63\%) than control $(12.82 \%)$, there was no significant difference between their fungicidal properties. Therefore, in order to draw a common fungicidal behavior among the latter three tested sulphur formulations other than IARI nano-S, data of both the methods were averaged and analyzed (Figure 1). It also revealed IARI nano-S as the best among all the sulphur forms to restrict conidial germination and thereby increasing the percentage of non-germinated conidia which was followed by Canadian nano-S, Merck sulphur and Sulphur 80WP. On the basis of

\begin{tabular}{|c|c|c|c|c|c|c|c|}
\hline \multirow[t]{2}{*}{ S.No. } & \multirow[t]{2}{*}{ Fungicides } & \multicolumn{3}{|c|}{ Food poison technique } & \multicolumn{3}{|c|}{ Detached leaf method } \\
\hline & & $\begin{array}{l}\% \text { Germination } \\
\text { of conidia }\end{array}$ & $\begin{array}{c}\% \text { Inhibition of conidial } \\
\text { germination }\end{array}$ & $\begin{array}{c}\% \text { Non-germinated } \\
\text { conidia }\end{array}$ & $\begin{array}{l}\% \text { Germination } \\
\text { of conidia }\end{array}$ & $\begin{array}{c}\% \text { Inhibition of } \\
\text { conidial germination }\end{array}$ & $\begin{array}{c}\% \text { Non-germinated } \\
\text { conidia }\end{array}$ \\
\hline 1 & IARI Nano Sulphur & $\begin{array}{c}2.95 \\
(9.09)\end{array}$ & $\begin{array}{c}84.03 \\
(67.86)\end{array}$ & $\begin{array}{c}97.03 \\
(80.84)\end{array}$ & $\begin{array}{c}0.00 \\
(0.025)\end{array}$ & $\begin{array}{l}100.00 \\
(90.00)\end{array}$ & $\begin{array}{l}100.00 \\
(90.00)\end{array}$ \\
\hline 2 & $\begin{array}{l}\text { Merck Sulphur } \\
\text { (AR commercial product) }\end{array}$ & $\begin{array}{c}11.94 \\
(19.15)\end{array}$ & $\begin{array}{c}47.49 \\
(42.88)\end{array}$ & $\begin{array}{c}87.99 \\
(71.79)\end{array}$ & $\begin{array}{c}4.46 \\
(11.90)\end{array}$ & $\begin{array}{c}95.52 \\
(78.04)\end{array}$ & $\begin{array}{c}95.53 \\
(78.06)\end{array}$ \\
\hline 3 & Sulphur 80 WP (Sulrex) & $\begin{array}{c}12.13 \\
(19.71)\end{array}$ & $\begin{array}{c}42.30 \\
(40.41)\end{array}$ & $\begin{array}{l}87.46 \\
(71.24)\end{array}$ & $\begin{array}{c}4.63 \\
(12.23)\end{array}$ & $\begin{array}{c}95.35 \\
(77.71)\end{array}$ & $\begin{array}{c}95.36 \\
(77.73)\end{array}$ \\
\hline 4 & Canadian Sulphur (Nano) & $\begin{array}{c}13.09 \\
(19.76)\end{array}$ & $\begin{array}{c}41.11 \\
(39.61)\end{array}$ & $\begin{array}{l}86.90 \\
(70.19)\end{array}$ & $\begin{array}{c}3.58 \\
(8.57)\end{array}$ & $\begin{array}{l}96.40 \mathrm{~s} \\
(81.38)\end{array}$ & $\begin{array}{c}96.41 \\
(81.39)\end{array}$ \\
\hline \multirow[t]{3}{*}{5} & Control & $\begin{array}{c}19.25 \\
(25.56)\end{array}$ & $\begin{array}{c}33.41 \\
(34.40)\end{array}$ & $\begin{array}{c}80.73 \\
(64.38)\end{array}$ & $\begin{array}{c}12.82 \\
(20.63)\end{array}$ & $\begin{array}{l}87.78 \\
(69.95)\end{array}$ & $\begin{array}{c}87.18 \\
(69.32)\end{array}$ \\
\hline & CD $(5 \%)$ & 9.45 & 19.17 & 9.44 & 8.90 & 9.10 & $\begin{array}{l}6.44 \\
(8.91)\end{array}$ \\
\hline & $\mathrm{CV}$ & & 22.26 & 6.91 & 26.07 & 5.99 & $\begin{array}{c}3.55 \\
(5.88)\end{array}$ \\
\hline
\end{tabular}

Table 1: Effect of various forms of sulphur (1000 ppm at $24 \mathrm{~h}$ ) on the conidial germination of Erysiphe cichoracearum. 


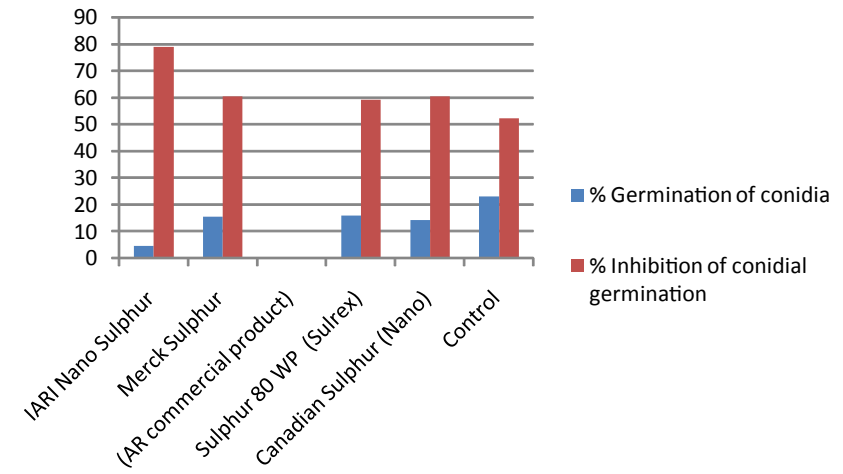

Figure 1: Effect of sulphur formulations $(0.1 \%$ at $24 \mathrm{~h})$ on the conidia of Erysiphe cichoracearum as determined by combination of poisoned food technique and detached leaf method.

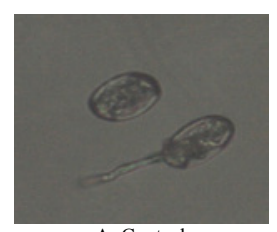

A: Control

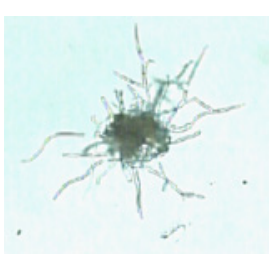

D: Sulphur 80WP

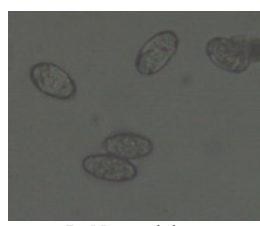

B: Nanosulphur

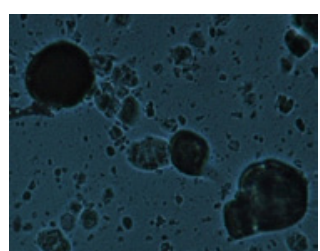

E: Nanosulphur
Figure 2: Conidial germination and cleistothecia of Erysiphe cichoracearum after 24 hours exposure to micronized sulphur and nano-sulphur (1000 ppm, at 10X).

conidial germination of E. cichoracearum, IARI nano-S was found four times better than the commercial product Sulphur 80WP and Merck sulphur and three times superior over Canadian nano-S. The efficacy of wettable sulfur has already been reported against powdery mildew of coriander [18-21] and sunflower [22]. But our study has proved that reduction in particle size enhances the effectiveness of sulphur particles as antimicrobial agent and thus newly synthesized IARI nano-S is more effective than the commercial micronized formulation. This modification of fungicidal formulation also facilitated their use even at lower amount with better efficacy. Unlike our study, Deshpande et al. [23] synthesized sulphur nanoparticles from hazardous $\mathrm{H} 2 \mathrm{~S}$ gas and reported its antimicrobial properties against bacteria (Pseudomonas areugenosa and Staphylococcus areus), yeast (Candida albicans) and mould fungi (Aspergillus flavus and A. niger). So, there might be possessing antibacterial property in IARI nano-S also in addition to fungicidal property which needs a further study.

During maintenance of the culture of E. cichoracearum in potted plants, many pin-point like black bodies immersed in the mycelial weft were noticed on the matured leaves of okra. Microscopic studies confirmed them as ascocarps (cleistothecia) of the causal fungus. Hence, few plants were sprayed with the suspension (1000 ppm) of IARI nano-S and Sulphur 80WP, and plain water was sprayed in control. It was observed that IARI nano-S not only affected germination of conidia in a greater extent as discussed above, but also severely affected the cleistothecial bodies (Figure 2). Further, the myceloid appendages and mycelia attached to the cleistothecia were reduced or shredded and also made the cleistothecia sterile that failed to release any asci or ascospores where as such changes in the cleistothecia were not visibly pronounced in case of Sulphur 80WP and control. The role of the appendages is probably to anchor the cleistothecia on the leaf surface, especially those bear trichomes, among which the appendages become entangled [24]. Therefore, it could be hypothesized that due to loss or absence of the appendages cleistothecia will not remain adhered to the host plant surface as a result of which the fungal pathogen will be either not able to complete life cycle on the host or no more aggravating the disease.

Apart from controlling fungal pathogens of crop plants sulphur nano-particles can contribute towards significant increase in growth and nutritive values of mung (Vigna radiata) as recorded in our earlier study [25]. It was also noted only a negligible change in the stress responsive elements $\left(\mathrm{H}_{2} \mathrm{O}_{2}\right.$, thiol, phenol, proline, carbonyl and lipid peroxidatiopn) of the sulphur nano-particles exposed mung plants as compared to the untreated control which suggested a safer use of nano sulphur in the fields of agriculture.

In conclusion, nanoparticles of sulphur are undoubtedly better in having fungicidal property as compared to those counterparts of conventional micronized formulations available in the markets. However, refinement of the protocol for synthesis of the sulphur nanoparticles will be required for further improvement in the efficacy of IARI nano-S as it was found only four times superior than the commercial formulation Suphur 80WP.

\section{Acknowledgements}

We thank National Agricultural Innovation Project-Indian Council of Agricultura Research (NAIP-ICAR) for providing financial assistance and sanctioning the project on nanopesticides.

\section{References}

1. Sridhar TS, Poonam S (1989) Assessment of loss caused by powdery mildew Erysiphe cichoracearum of okra Hibiscus esculentus and its control. Indian J Agric Sci 59: 606-607.

2. Sridhar SS (1985) Disease thresholds for powdery mildew of okra. Seeds and Farms 11: 36-38

3. Ramakrishnan L, Thumburaj S, Kamalanathan S, Krishnamurthy CS (1973) Control of powdery mildew of bhendi (Abelmoschos esculentus) with systemic fungicides. Madras Agricultural Journal 60: 605-606.

4. Yanar Y, Yanar D, Gebologlu N (2011) Control of powdery mildew (Leveillula taurica) on tomato by foliar sprays of liquid potassium silicate $\left(\mathrm{K}_{2} \mathrm{SiO}_{3}\right)$. African J Biotechnol 10: 3121-3123.

5. Holb IJ, Jong PF De, Heijne B (2005) Efficacy and phytotoxicity of lime sulphur in organic apple production. Ann Appl Biol 142: 225-233.

6. Gogoi R, Dureja PS, Pradeep K (2009) Nanoformulations-A safer and effective option for agrochemicals. Indian Farming 59: 7-12.

7. Roy Choudhury S, Nair KK, Kumar R, Gogoi R, Srivastava C, et al. (2010) Nanosulfur: a potent fungicide against food pathogen, Aspergillus niger. AIP Conf Proc 1276: 154-157.

8. Kumar R, Nair KK, Alam MI, Gogoi R, Singh PK, et al. (2011) A simple method for the estimation of sulfur in nanoformulations by UV spectrophotometery. Curr Sci 100: 1542-1546.

9. Scherer HW (2001) Sulphur in crop production. Eur J Agron 14: 81-111.

10. Lee J, Lee HJ, Park JD, Lee SK, Lee SI, et al. (2008) Anti-cancer activity of highly purified sulphur in immortalized and malignant human oral keratinocytes. Toxicol In Vitro 22: 87-95

11. Williams JS, Cooper RM (2004) The oldest fungicide and newest phytoalexin-a reappraisal of the fungitoxicity of elemental sulphur. Plant Pathol 53: 263-279. 
Citation: Gogoi R, Singh PK, Kumar R, Nair KK, Alam I, et al. (2013) Suitability of Nano-sulphur for Biorational Management of Powdery mildew of Okra (Abelmoschus esculentus Moench) caused by Erysiphe cichoracearum. J Plant Pathol Microb 4: 171 doi:10.4172/2157-7471.1000171

12. Bostanian NJ, Thistlewood HM, Hardman JM, Recette G (2009) Toxicity of six novel fungicides and sulphur to Galendromus accidentalis (Acari: Phytoseiidae). Exp Appl Acarol 47: 63-69.

13. Wang Z, Wei Z, Wang Z, Li Z, Wu T, et al. (2007) Novel nanosize absorbing composite cathode materials for the next generational lithium battery. Journal of Wuhan University of Technology Material Science and Education 22: 234-239.

14. Johnson NC, Manchester S, Sarin L, Gao Y, Kulaots I, et al. (2008) Mercury vapor released from broken compact fluorescent lamps and in situ capture by new nanomaterial sorbents. Environ Sci Technol 42: 5772-5778.

15. Fuhrmann M, Malemed D, Kalb PD, Adams JW, Milian LW (2002) Sulfur polymer solidification/ stabilization of elemental mercury waste. Waste Manag 22: 327-333.

16. Kitao Y, Doazan JP (1989) Grapevine breeding for resistance to powdery mildew. Bioassay system for evaluation of plant resistance and for characterization of different Uncinula necator stains. Proceedings of International Symposium on Grape Breeding, France 239-244.

17. Varalakshmi S, Raguchander T, Kuttalam S, Samiyappan P (1999) Bioefficacy and persistence of hexaconazole against mildew of grapes. Pestology 23: 2226.

18. Srivastava US, Rai RA, Agrawat JM (1972) Powdery mildew of coriander and its control. Indian Phytopathol 24: 437-440.
19. Keshwal RL, Choubey PC, Singh K (1979) Effect of different dates of sowing and fungicidal spray on the incidence of powdery mildew of coriander Pesticides 13: 25.

20. Ali SA, Pathak RK, Saraf RK (1998) Fungicidal seed treatment in coriander. Adv Plant Sci 11: 303-304.

21. Singh AK (2006) Evaluation of fungicides for the control of powdery mildew disease in coriander (Coriandrum sativum L.). Journal of Spices and Aromatic Crops 15: 123-124.

22. Dinesh BM, Shripad K, Harlapur SI, Benagi VI (2011) Management of Sunflower Powdery mildew (Erysiphe cichoracearum). J Mycol PI Pathol 41: 49-52.

23. Deshpande AS, Ramdas BK, Bhalchandra KV, Renuka MJ, Arti SH, et al. (2008) Sulfur nanoparticles synthesis and characterization from H2S gas, using novel biodegradable iron chelates in W/O microemulsion. Nanoscale Res Lett 3: 221-229.

24. Alexopoulos CJ, Mims CW, Blackwell M (1996) Phylum Ascomycota. In Introductory Mycology. (4thedn), John Wiley \& Sons, Inc, New York 472.

25. Patra P, Roy Chaudhury S, Mandal S, Basu A, Gogoi R, et al. (2011) Effect of sulphur and $\mathrm{ZnO}$ nanoparticles on stress physiology and plant (Vigna radiata) nutrition. $2^{\text {nd }}$ International Conference on Advanced Nanomaterial and Nanotechnology (ICANN-2011), 8-10 December, 2011, Indian Institute of Technology, Guwahati, India. 